\title{
Distribution and Diversity of Anaerobic Ammonium Oxidation (Anammox) Bacteria in the Sediment of a Eutrophic Freshwater Lake, Lake Kitaura, Japan
}

\author{
IkUo Yoshinaga ${ }^{1}$, Teruki Amano ${ }^{1}$, TAKao Yamagishi ${ }^{2}$, Kentaro OKadA $^{1}$, Shingo UedA ${ }^{3}$, Yoshihiko SAKO ${ }^{1}$, \\ and YUICHI SUWA ${ }^{2 *, \dagger}$ \\ ${ }^{1}$ Laboratory of Marine Microbiology, Division of Applied Biosciences, Graduate School of Agriculture, Kyoto University, \\ Kitashirakawa-Oiwake-cho, Sakyo-ku, Kyoto 606-8502, Japan; ${ }^{2}$ Research Institute for Environmental Management Technology, \\ National Institute of Advanced Industrial Science and Technology, 16-1, Onogawa, Tsukuba, Ibaraki 305-8569, Japan; and \\ ${ }^{3}$ College of Bioresource Sciences, Nihon University, 1866, Kameino, Fujisawa, Kanagawa 252-0880, Japan
}

(Received October 19, 2010-Accepted April 2, 2011—Published online May 11, 2011)

\begin{abstract}
Although the emission of $\mathrm{N}_{2}$ via anaerobic ammonium oxidation (anammox) is a key process in the elimination of nitrogenous compounds from aquatic environments, little information is available regarding its significance and the relevant microorganisms (anammox bacteria) in eutrophic freshwater lakes. In the present study, the anammox bacteria in the sediment of a eutrophic lake in Japan, Lake Kitaura, were examined using a ${ }^{15} \mathrm{~N}$-tracer technique to measure their potential anammox activity. Potential anammox activity was localized to the northern region of the lake where a stable supply of both $\mathrm{NH}_{4}{ }^{+}$and $\mathrm{NO}_{3}{ }^{-}$existed in the sediment. These results suggest the contribution of anammox bacteria to the total emission of $\mathrm{N}_{2}$ from sediment in this eutrophic lake to not be negligible. Moreover, selective PCR successfully amplified anammox bacteria-related (Brocadiales-related) 16S rRNA genes from sediment samples in which potential anammox activity was observed. The clone libraries consisted of diverse phylotypes except the genus "Scalindua"-lineages, and the lineages of genus "Brocadia" were dominantly recovered, followed by the genus "Kuenenia"-lineages. Most of them, however, were novel and phylogenetically distinguishable from known Brocadiales species. A unique population of anammox bacteria inhabits and potentially contributes to the emission of $\mathrm{N}_{2}$ from Lake Kitaura.
\end{abstract}

Key words: anammox, freshwater lake, ${ }^{15} \mathrm{~N}$-tracer, $16 \mathrm{~S}$ rRNA gene

The eutrophication of freshwater lake ecosystems, especially those located in populated and industrialized areas, is a major environmental concern all over the world (26). Large freshwater lakes have served as natural reservoirs for agricultural, industrial, and potable water resources. However, they frequently receive high carbonaceous, phosphorus and nitrogenous loads from terrestrial sources via rivers, streams, and/or ground water causing algal blooms and a deterioration of water quality (26). Understanding the mechanisms of the nitrogen cycle in freshwater lakes is especially important, and we must revise our knowledge with newly described processes, including anaerobic ammonium oxidation (anammox). Microbial $\mathrm{N}_{2}$ emission is a key process in the elimination of nitrogen, but little information is available regarding the contribution of anammox to $\mathrm{N}_{2}$ emissions in eutrophic lakes threatened by eutrophication.

Anammox has been recently recognized as an alternative microbial metabolic pathway other than the denitrification involved in $\mathrm{N}_{2}$ emission. A monophyletic bacterial group (order Brocadiales) deeply branched in the phylum Planctomycetes is now known to mediate the anammox pathway in which the electron donor, ammonium $\left(\mathrm{NH}_{4}^{+}\right)$, is anaerobically oxidized by the electron acceptor, nitrite $\left(\mathrm{NO}_{2}^{-}\right)(14,33)$. Since the discovery of anammox in the sea bed of a continental shelf

\footnotetext{
* Corresponding author. E-mail: y-suwa@bio.chuo-u.ac.jp; Tel: +81-(0)3-3817-1653; Fax: +81-(0)3-3817-1651.

† Present address: Department of Biological Sciences, Chuo University, 1-13-27, Kasuga, Bunkyo-ku, Tokyo 112-8551, Japan
}

slope (29), an increasing number of reports have demonstrated that the pathway is present in various marine ecosystems and may involve in the nitrogen cycle $(7,24)$. A few studies reported anammox activity in freshwater and estuarine sediments $(2,3,6,16,18,30)$ as well as in anoxic water columns of permanently stratified lakes in tropical (25) and temperate areas (9). However, the significance and diversity of anammox bacterial populations in freshwater ecosystems are not fully understood.

Based on enrichment culture studies, five candidate genera in the order Brocadiales (Candidatus "Anammoxoglobus", "Brocadia", "Jettenia", "Kuenenia", and "Scalindua") have been proposed as anammox bacteria (14), although no isolate has been established so far. Small subunit ribosomal RNA (16S rRNA) gene analyses have revealed that all the known anammox bacteria belong to a monophyletic branch (order Brocadiales), and the monophyleticity enables us to elucidate the bacteria involved in anammox pathways in nature, through molecular techniques targeting 16S rRNA and its gene (14, 23). It has been hypothesized that "Scalindua"-like species primarily compose anammox bacterial populations in aquatic environments, in water and sediment $(14,17,18,24)$. Recently, "Brocadia"- and "Kuenenia"-like species were also detected in sediment samples of mesohaline $(2,3)$, oligohaline (6), and freshwater areas (35) of several river systems. In addition, 16S rRNA gene fragments from the "Kuenenia" "Brocadia", "Anammoxoglobus" and "Jettenia" lineages were also detected in various terrestrial ecosystems including lake shores, a contaminated porous aquifer, permafrost soil, 
agricultural soil (12), and a hot spring (13).

In this study, we conducted a survey of anammox bacteria in the sediment of a shallow freshwater lake in Japan, Lake Kitaura. The lake is hyper-eutrophic and receives high nitrogen loads from surrounding cities, agricultural fields, livestock farms and so on, resulting in frequent harmful algal blooms of cyanobacteria and diatoms in the middle to southern region of the lake (10). Here we measured potential anammox activity in sediment at several sampling points in Lake Kitaura using a ${ }^{15} \mathrm{~N}$-labeled tracer, because anammox may play a significant role in the emission of $\mathrm{N}_{2}$ gas from nitrogenous contaminants. We also analyzed the population structure of anammox bacteria in Lake Kitaura through clone libraries constructed with amplified 16S rRNA genes by selective PCR for the "Brocadiales"-lineages to compare the anammox bacterial species that have been detected so far in nature.

\section{Materials and Methods}

\section{The lake}

Sediment samples were collected from Lake Kitaura, one of three contiguous lakes of known collectively as Lake Kasumigaura, the second largest $\left(220 \mathrm{~km}^{2}\right)$ freshwater lake in Japan (Fig. 1). The three lakes ultimately empty into one river at the southern end of Lake Sotona-Sakaura, which flows into the Pacific Ocean. Lake Kitaura $\left(36 \mathrm{~km}^{2}\right)$ is long and narrow with an average depth of ca. $4.8 \mathrm{~m}$ and maximum depth of ca. $7 \mathrm{~m}$ (Fig. 1). The water in this lake slowly flows from north to south. Among the 22 rivers that flow into Lake Kitaura, the Tomoe and Hokota rivers, which flow into the northern end, are major carriers of terrestrial nutrients, including nitrogen, of domestic, agricultural, and industrial origins (Fig. 1).

\section{Sampling of sediment and water at the bottom of the lake, and preparation of pore water from sediment samples}

Samplings for the anammox survey were conducted on August 1, October 17, and November 8 in 2005, and April 17 and June 7 in 2006, mainly in the northern area of Lake Kitaura. Sediment was sampled using a modified Ekman-Birge sediment core sampler (Rigo Co., Tokyo, Japan) with an acrylic resin tube $(30 \mathrm{~cm}$ in length, 10 $\mathrm{cm}$ in diameter) inside. After the core sampler was raised to the boat, the water over the sediment was collected with a syringe as "bottom water". The fluffy surface layer $(0-2 \mathrm{~cm}$ beneath the sediment surface; fs-layer), and the subsurface layer $(10-12 \mathrm{~cm}$

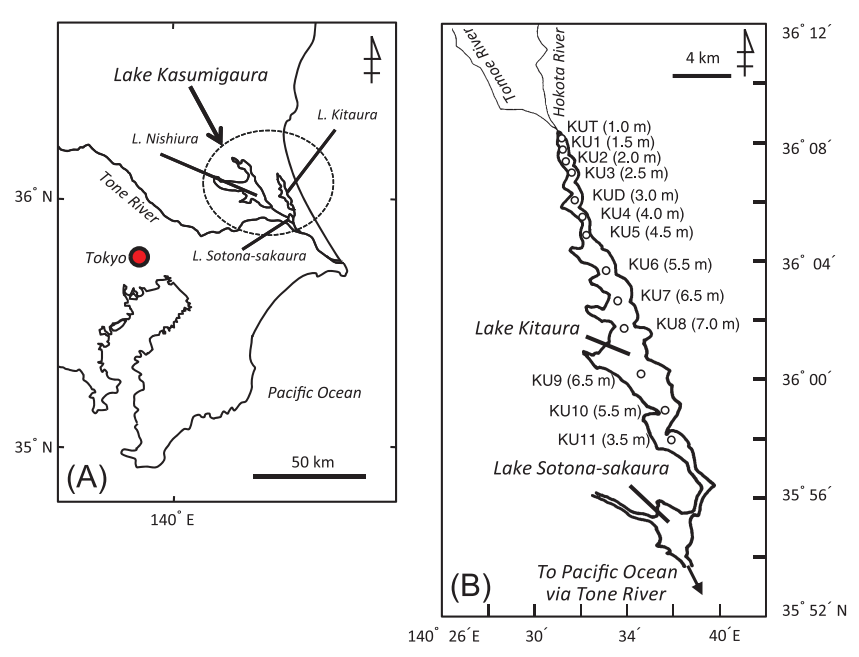

Fig. 1. Location of Lake Kasumigaura (A) and sampling stations in Lake Kitaura (B). beneath the sediment surface; ss-layer) of the core samples were carefully collected and transferred into plastic containers. The surface layer (fs-layer) of sediment samples was generally unpacked and fluffy in texture, and appeared to easily disperse in the water stream. Therefore, we also obtained sediment in the ss-layer from each core sample. The ss-layer was packed compared with the fslayer regardless of the sampling location and season. The water content of ss-layer samples ranged $82-84 \%$ and $86-87 \%$ at stations KU3 and KU4 respectively, whereas the fs-layer samples contained $86-91 \%$ water at KU3 and $89-92 \%$ at KU4. A horizontal distribution survey from north to south of Lake Kitaura was conducted on November 8 in 2005, and the ss-layer of sediment was collected at each sampling site (Fig. 1). The sediment and bottom water samples were immediately placed on ice until transportation to the laboratory where the samples were stored at $4^{\circ} \mathrm{C}$ in the dark. The pore water of each sediment layer was recovered within 4 hours after collection by centrifugation at $10,000 \times g$ for $20 \mathrm{~min}$. The pore water and bottom water samples were immediately filtered through a $0.45-\mu \mathrm{m}$ cellulose ester membrane (Advantech Toyo Kaisha, Tokyo, Japan) to remove biotic and abiotic particles. Potential anammox and denitrification activity in both layers of sediment samples was measured within 4 days after procurement.

Chemical analysis of water samples

The $\mathrm{NO}_{3}{ }^{-}, \mathrm{NO}_{2}{ }^{-}, \mathrm{NH}_{4}{ }^{+}$, and $\mathrm{SO}_{4}{ }^{2-}$ concentrations in bottom water and pore water from the sediment samples were determined using an ion chromatograph (HIC-6A; Shimadzu, Kyoto, Japan) for cations, a HPLC equipped with a diode array for $\mathrm{NO}_{3}{ }^{-}$and $\mathrm{NO}_{2}{ }^{-}$ (HP 1100; Hewlett-Packard, Palo Alto, CA, USA), and an IC7000 (Yokogawa Analytical Supply, Tokyo, Japan) for $\mathrm{SO}_{4}{ }^{2-}$.

\section{Determination of potential anammox and denitrification activities using $a^{15} \mathrm{~N}$-tracer}

The potential anammox and denitrification activities of sediment samples were determined using a ${ }^{15} \mathrm{~N}$-tracer technique based in principle on the method described by Thamdrup and Dalsgaard (29). Reactive substrates for anammox were added to the vials in the following three combinations to determine the activities of the samples: (i) $0.4 \mathrm{mM}$ unlabeled $\mathrm{NH}_{4} \mathrm{Cl}+1 \mathrm{mM} \mathrm{Na}{ }^{15} \mathrm{NO}_{2}$, (ii) 0.4 $\mathrm{mM}^{15} \mathrm{NH}_{4} \mathrm{Cl}+1 \mathrm{mM}$ unlabeled $\mathrm{NaNO}_{2}$, and (iii) $0.4 \mathrm{mM}^{15} \mathrm{NH}_{4} \mathrm{Cl}$ without nitrite. During anaerobic incubation with substrate combinations (i) and (ii), $\mathrm{NO}_{2}^{-}$-dependent anammox can be detected by the production of ${ }^{14} \mathrm{~N}^{15} \mathrm{~N}\left({ }^{29} \mathrm{~N}_{2}\right)$, because anammox utilizes one mole each of $\mathrm{NH}_{4}{ }^{+}$and $\mathrm{NO}_{2}{ }^{-}$(14). Substrate combination (iii) was a negative control to examine whether anammox occurs without nitrite. It also served as a negative control to examine oxygen contamination. If oxygen was present, ${ }^{15} \mathrm{~N}$-labeled $\mathrm{N}_{2}$ would be produced via aerobic nitrification and subsequent denitrification. Denitrification activity was determined by the production of ${ }^{15} \mathrm{~N}^{15} \mathrm{~N}$ $\left({ }^{30} \mathrm{~N}_{2}\right)$ following anaerobic incubation with combination (i). In this study, nitrite (labeled or unlabeled) was added at a relatively high concentration $(1 \mathrm{mM})$ in order to maintain nitrite long enough to successfully detect anammox activity, because generally the denitrifiers abundant in the samples consume nitrite rapidly. In fact, at least a half of the nitrite added remained at the end of incubation. The amount of ammonium $(0.4 \mathrm{mM})$ added to the sediment suspension was about three-fold as much as that present in the sediment to keep the labeling ratio of ${ }^{15} \mathrm{NH}_{4}$ high during the incubation with substrate combination (ii).

Sediment samples were suspended at a ratio of 1:3 in Ar-purged oxygen-free inorganic medium modified by replacing $5 \mathrm{mM} \mathrm{KHCO}_{3}$ (34) with $5 \mathrm{mM} \mathrm{NaHCO}$. The suspension was thoroughly purged with argon gas (Ar) and the dissolved oxygen (DO) was monitored with a handheld meter (HQ-10; HACH, Loveland, CO, USA) until below the detectable limit. If necessary, the $\mathrm{pH}$ of the suspension was adjusted to 7.6 with $1 \mathrm{~N} \mathrm{HCl}$ or $1 \mathrm{~N} \mathrm{NaOH}$. Portions $(40 \mathrm{~mL})$ of the oxygen-free sediment suspension were immediately transferred to $67-\mathrm{ml}$ glass vials in an anaerobic globe box (COY Laboratory Products, Grass Lake, MI, USA) filled with $\mathrm{Ar}+5 \%$ 
$(\mathrm{v} / \mathrm{v}) \mathrm{H}_{2}$, and the vials were capped with butyl rubber stoppers and aluminum seals. The headspace gas of the vials was replaced with ultra pure helium $(\mathrm{He})(>99.9999 \%)$ by repeated vacuuming and purging with a gas-exchange manifold (Sanshin Kogyo, Yokohama, Japan). Positive pressure (0.15 $\mathrm{MPa})$ was added to the headspace to prevent unintentional contamination with ambient air during the incubation and gas sampling. Prior to adding the reactive substrates for anammox, vials containing oxygen-free sediment suspensions were pre-incubated overnight in the dark at $20^{\circ} \mathrm{C}$ in order to thoroughly eliminate the remaining nitrite, nitrate, $\mathrm{DO}$, and $\mathrm{O}_{2}$ in the headspace; otherwise, for example, if exogenous unlabeled nitrite remained in the incubation vial with ${ }^{15} \mathrm{~N}$-labeled $\mathrm{NaNO}_{2}$, undesired ${ }^{29} \mathrm{~N}_{2}$ production via denitrification interferes with the estimation of anammox activity. Oxygen-free stock solutions $(100 \mathrm{mM})$ of ${ }^{15} \mathrm{~N}$-labeled $\mathrm{NH}_{4} \mathrm{Cl}$ (Shoko-Co., Tokyo, Japan, ${ }^{15} \mathrm{~N}$ atom\%: 99.92), ${ }^{15} \mathrm{~N}$-labeled $\mathrm{NaNO}_{2}$ (Isotec, OH, USA, ${ }^{15} \mathrm{~N}$ atom\%: 99.69), unlabeled $\mathrm{NH}_{4} \mathrm{Cl}$, and unlabeled $\mathrm{NaNO}_{2}$ (Wako, Osaka, Japan) were prepared, and added with a gas-tight syringe to the vials at the final concentrations mentioned earlier. It should be noted that commercially supplied unlabeled reagents of $\mathrm{NH}_{4} \mathrm{Cl}$ and $\mathrm{NaNO}_{2}$ are regarded to contain the isotopologues ${ }^{15} \mathrm{NH}_{4} \mathrm{Cl}$ and $\mathrm{Na}^{15} \mathrm{NO}_{2}$, at the natural abundance of ${ }^{15} \mathrm{~N}, 0.366 \%$. Hence the effect of these isotopologues must be corrected for calculating rates of anammox and denitrification. Vials were incubated at $20^{\circ} \mathrm{C}$ with stirring at $150 \mathrm{rpm}$ on a magnetic stirrer and $100 \mu \mathrm{L}$ of headspace gas was collected every 1-6 hours from each vial under anaerobic conditions (see the supplementary text). The anaerobic incubation was performed in duplicate. The headspace gas samples were immediately loaded into a quadrupole GC-MS system (6890N-5973 inert, Agilent Technologies, Santa Clara, CA, USA) to quantify each $\mathrm{N}_{2}$ isotopologue $\left({ }^{14} \mathrm{~N}^{14} \mathrm{~N},{ }^{14} \mathrm{~N}^{15} \mathrm{~N},{ }^{15} \mathrm{~N}^{15} \mathrm{~N}\right)$, in the manner shown in the supplementary text. The quantity (in moles) of each $\mathrm{N}_{2}$ isotopologue was determined with a standard curve prepared with mixture of ${ }^{15} \mathrm{~N}^{14} \mathrm{~N}$ and ${ }^{15} \mathrm{~N}^{15} \mathrm{~N}$ at known concentrations with ultra pure $\mathrm{He}$ as a background gas. The amount of isotopologue was quantified using Bunsen's solubility coefficient for gaseous $\mathrm{N}_{2}$ to water.

We obtained the time course of ${ }^{29} \mathrm{~N}_{2}$ and ${ }^{30} \mathrm{~N}_{2}$ production $\left(N_{29}\right.$ and $N_{30}$ ) in the vials, to estimate potential anammox and denitrification rates, respectively. It is presumed that the ${ }^{29} \mathrm{~N}_{2}$ in each vial with combination (i) is primarily produced via anammox. However, denitrification could also produce ${ }^{29} \mathrm{~N}_{2}$, because the reagent of ${ }^{15} \mathrm{~N}$-labeled $\mathrm{NO}_{2}{ }^{-}$contained $0.31 \%{ }^{14} \mathrm{NO}_{2}{ }^{-}$, with substrate combination (ii), the commercially supplied nitrite reagent probably contains ${ }^{15} \mathrm{NO}_{2}{ }^{-}$at the same percentage as the natural abundance of ${ }^{15} \mathrm{~N}$, $0.366 \%$. Furthermore, atmospheric $\mathrm{N}_{2}$ contamination during the sample preparation and gas analysis procedures brings about $0.732 \%$ ${ }^{29} \mathrm{~N}_{2}$, which could also be a cause of overestimation of anammox. Our procedures for calibration were consistent with a theory developed previously (27)

When reactive substrates (including the ${ }^{15} \mathrm{~N}$-tracer) were supplied with the combination (i), the net $\mathrm{N}_{2}$ production via anammox $\left(N_{A M X}\right)$ was calculated from the amount of each $\mathrm{N}_{2}$ isotopologue $\left(N_{28}, N_{29}\right.$, and $N_{30}$ ) quantified with GC-MS according to the equation below.

$$
\begin{aligned}
& N_{A M X}=\left[N_{29}-2 N_{28} r_{15 s} /\left(1-r_{15 s}\right)-2 N_{30}\left(1-r_{15 n}\right) / r_{15 n}\right] / \\
& {\left[r_{15 s}\left(1-r_{15 n}\right)+\left(1-r_{15 s}\right) r_{15 n}\right]}
\end{aligned}
$$

The ${ }^{15} \mathrm{~N}$-labeling ratio of the $\mathrm{NO}_{2}{ }^{-}$pool in each vial $\left(r_{15 n}\right)$ was assumed to be the same as the labeling ratio of the reagent added, and the natural abundance of ${ }^{15} \mathrm{~N}$ in atmospheric $\mathrm{N}_{2}$ gas $\left(r_{15 s}\right)$, $0.366 \%$. With substrate combination (i), ${ }^{15} \mathrm{NO}_{2}{ }^{-}$also works as a tracer to determine potential denitrification activity. The net $\mathrm{N}_{2}$ production via denitrification $\left(N_{D E N}\right)$ was determined with eq. 2

$$
N_{D E N}=N_{30} / r_{15 n^{2}}
$$

When ${ }^{15} \mathrm{~N}$-labeled ammonium and unlabeled nitrite were added to the incubation vials with combination (ii), $N_{A M X}$ was calculated by eq. 3 , using the ${ }^{15} \mathrm{~N}$-labeling ratio of $\mathrm{NH}_{4}^{+}$pool in each vial $\left(r_{15 a}\right)$. The measured $N_{29}$ must be calibrated under the presumption that the unlabeled nitrite reagent contained ${ }^{15} \mathrm{NO}_{2}$ at the natural abundance of ${ }^{15} \mathrm{~N}$ and the denitrification produced ${ }^{29} \mathrm{~N}_{2}$ from ${ }^{15} \mathrm{NO}_{2}$ and ${ }^{14} \mathrm{NO}_{2}$ of the reagent. This calibration is especially important when the denitrification activity in a sample is much higher than the anammox activity.

$$
N_{A M X}=\left[N_{29}-2 N_{28} r_{15 s} /\left(1-r_{15 s}\right)\right] /\left[r_{15 a}\left(1-r_{15 s}\right)-r_{15 s}\left(1-r_{15 a}\right)\right]
$$

A detailed explanation of the calibration method is given in the supplementary text.

\section{PCR-clone library analysis targeting $16 S \mathrm{rRNA}$ genes of anammox} bacteria

The PCR-clone library analysis targeting 16S rRNA genes of anammox bacteria was performed with environmental DNA extracted from sediment sampled on November 8, 2005 in the same manner as described previously (2). The selective PCR primers for the anammox bacteria-related 16S RNA gene were AMX368F (forward primer, TTCGCAATGCCCGAAAGG), AMX820R (reverse primer, AAAACCCCTCTACTTAGTGCCC) and BS820R (reverse primer, TAATTCCCTCTACTTAGTGCCC). The thermal program consisted of an initial denaturation step at $94^{\circ} \mathrm{C}$ for $4 \mathrm{~min}$; followed by 30 cycles of denaturation at $94^{\circ} \mathrm{C}$ for $30 \mathrm{~s}$, annealing at $56^{\circ} \mathrm{C}$ for $30 \mathrm{~s}$, and elongation at $72^{\circ} \mathrm{C}$ for $1 \mathrm{~min}$; and a final extension step at $72^{\circ} \mathrm{C}$ for $7 \mathrm{~min}$. The products were ligated into the pGEM-T Easy Vector (Promega, Madison WI, USA), and transformed into E. coli INVaF' (Invitrogen, Carlsbad, CA, USA). More than 40 clones from each clone library of 16S rRNA gene were sequenced with an ABI 3730xl (Applied Biosystems, Carlsbad, CA, USA) using the sequencing service provided by Dragon Genomics Center (Takara Bio, Otsu, Japan). After the checking of possible chimeric artifacts with the Bellerophon program (11), the sequences were examined for phylogenetic affiliations by comparing them with known anammox bacterial candidates in DDBJ/EMBL/ GenBank databases with NCBI-BLAST 2.2.12 (1). Sequences with greater than $83 \%$ similarity to any of the anammox bacterial candidates were aligned and analyzed with the neighbor-joining method (21) using CLUSTALW (5). Kimura's two-parameter correction was used and all other settings were default. The DOTUR program (22) was used to separate the sequences into operational taxonomic units (OTUs) following the calculation of phylogenetic distance by the DNADIST program in the Philip package. For comparing the diversity and relatedness of anammox bacteria among different sediment samples, diversity indices were determined by the DOTUR program and a principal coordinates analysis was performed using UNIFRAC (15) software.

\section{Nucleotide sequence accession numbers}

The nucleotide sequence data reported in this study are available in the DDBJ/EMBL/GenBank databases under the accession numbers AB509308 to AB509339 for the 32 OTUs.

\section{Results and Discussion}

\section{Determination of potential anammox and denitrification activities in sediment}

Fig. 2a demonstrates the typical course of net $\mathrm{N}_{2}$ production via anammox $\left(N_{A M X}\right)$ in the ss-layer of a sediment sample obtained on August 1, 2005. Reactive substrates were added to anaerobic incubation vials in either of the following combinations: (i) unlabeled $\mathrm{NH}_{4}{ }^{+}+{ }^{15} \mathrm{~N}$-labeled $\mathrm{NO}_{2}{ }^{-}$or (ii) ${ }^{15} \mathrm{~N}$-labeled $\mathrm{NH}_{4}{ }^{+}+$unlabeled $\mathrm{NO}_{2}{ }^{-}$. Regardless of the substrate combinations, $N_{A M X}$ increased linearly without delay and zero-order reaction kinetics were observed. Similar potential anammox rates, 16.6 and $15.0 \mathrm{nmol}-\mathrm{N}_{2} \mathrm{~cm}^{-3} \mathrm{~h}^{-1}$, were obtained with combinations (i) and (ii), respectively. We used 

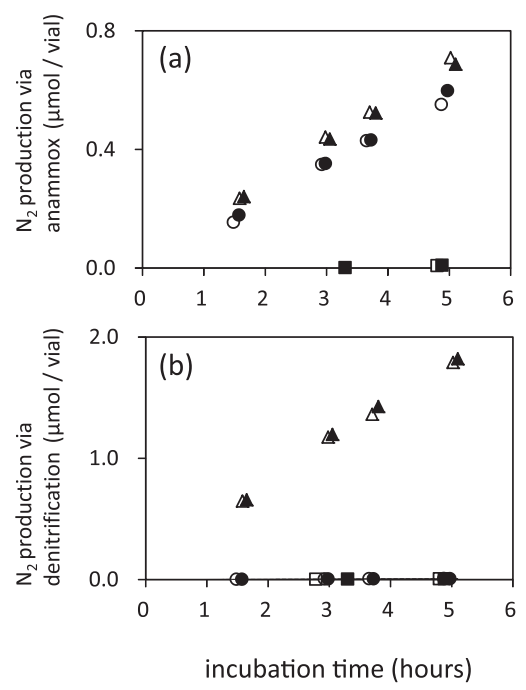

Fig. 2. $\mathrm{N}_{2}$ production via (a) anammox and (b) denitrification estimated from the accumulation of $\mathrm{N}_{2}$ isotopologues during anaerobic incubation of sediment suspensions with $\mathrm{NH}_{4}{ }^{+}+{ }^{15} \mathrm{NO}_{2}{ }^{-}$(triangles), ${ }^{15} \mathrm{NH}_{4}^{+}+\mathrm{NO}_{2}{ }^{-}$(circles) or ${ }^{15} \mathrm{NH}_{4}{ }^{+}$alone (squares). The sediment samples were collected from the ss-layer $(10-12 \mathrm{~cm})$ at station KU3 on August 1,2005 . Open and closed symbols represent a single vial in duplicate experiments.

the rates from substrate combination (ii) for the following analyses because they were usually lower than those obtained with combination (i) (the difference was 30\%) and less likely to be overestimated. No $N_{A M X}$ was detected in the negative control, in which ${ }^{15} \mathrm{NH}_{4} \mathrm{Cl}$ was added without nitrite (Fig. $2 \mathrm{a}$ ), indicating that anammox bacteria occurred in the sediments tested. Our results also indicated that the ${ }^{15} \mathrm{~N}$ labeling ratios of $\mathrm{NO}_{2}^{-}\left(r_{15 n}\right)$ and $\mathrm{NH}_{4}^{+}\left(r_{15 a}\right)$ in the sediment suspension were enough to detect anammox activity. Potential denitrification activity was also estimated as a zero-order rate constant of the net $\mathrm{N}_{2}$ produced via denitrification $\left(N_{D E N}\right)$ derived from added ${ }^{15} \mathrm{NO}_{2}{ }^{-}$in anaerobic incubation with substrate combination (i) (Fig. 2b).

\section{Sediment layers in which potential anammox activity was detected}

Potential anammox activity was detected in the fs-layer $(0-2 \mathrm{~cm}$ in depth) and the ss-layer $(10-12 \mathrm{~cm})$ in samples from five stations (KUT, KU3, KUD, KU4 and KU5) in the northern region of Lake Kitaura (Table 1). Anammox activity was detected in both layers in most samples but tended to be higher in the ss-layer, except in the sample from station KU4 on October 17, 2005. More anammox activity (Wilcoxon signed-rank test, $P<0.05$ ) was observed in the ss-layers than fs-layers at stations KU4 and KU3. To our knowledge, anammox activity in sediment down to a depth of $10 \mathrm{~cm}$ has not been reported previously.

In our study, we used a chemically defined medium, instead of natural lake water, to measure the anammox activity in sediment, because of the higher concentration of nitrate (corresponding to $300 \mu \mathrm{M}$ in Lake Kitaura, Table 2) in the lake water than in other studies on marine and freshwater anammox bacteria. Furthermore, the unpredictable and considerable variability of chemical conditions in the lake, especially nitrate concentrations, would complicate analysis
Table 1. Rates of potential anammox and denitrification activities $\left(\right.$ nmol- $\left.\mathrm{N}_{2} \mathrm{~cm}^{-3} \mathrm{~h}^{-1}\right)$ in the fs-layer $(0-2 \mathrm{~cm})$ and ss-layer $(10-12 \mathrm{~cm})$ of sediment collected from five stations (KUTKU5) in Lake Kitaura

\begin{tabular}{lccccc}
\hline \multicolumn{1}{c}{ Samples } & KUT & KU3 & KUD & KU4 & KU5 \\
\hline August 1,2005 & & & & & \\
anammox $(0-2 \mathrm{~cm})$ & - & 10.4 & - & 2.95 & - \\
anammox $(10-12 \mathrm{~cm})$ & - & 15.0 & - & 4.58 & - \\
denitrification $(0-2 \mathrm{~cm})$ & - & 32.6 & - & 52.9 & - \\
denitrification $(10-12 \mathrm{~cm})$ & - & 41.5 & - & 49.9 & - \\
October 17, 2005 & & & & & \\
anammox $(0-2 \mathrm{~cm})$ & nd & 9.26 & - & 2.61 & - \\
anammox $(10-12 \mathrm{~cm})$ & nd & 10.5 & - & 2.41 & - \\
denitrification $(0-2 \mathrm{~cm})$ & 92.0 & 21.0 & - & 37.7 & - \\
denitrification $(10-12 \mathrm{~cm})$ & 86.9 & 37.5 & - & 36.1 & - \\
April 17, 2006 & & & & & \\
anammox $(0-2 \mathrm{~cm})$ & - & 7.48 & 3.27 & 2.67 & - \\
anammox $(10-12 \mathrm{~cm})$ & - & 11.5 & 8.39 & 4.26 & - \\
denitrification $(0-2 \mathrm{~cm})$ & - & 26.8 & 20.8 & 71.7 & - \\
denitrification $(10-12 \mathrm{~cm})$ & - & 33.3 & 34.4 & 47.9 & - \\
June 6, 2006 & & & & & \\
anammox $(0-2 \mathrm{~cm})$ & - & 3.77 & - & 2.49 & 0.56 \\
anammox $(10-12 \mathrm{~cm})$ & - & 8.41 & - & 5.02 & 0.87 \\
denitrification $(0-2 \mathrm{~cm})$ & - & 21.8 & - & 26.4 & 21.3 \\
denitrification $(10-12 \mathrm{~cm})$ & - & 19.2 & - & 42.2 & 30.9 \\
\hline Anam
\end{tabular}

Anammox rates were estimated from anaerobic incubation with ${ }^{15} \mathrm{NH}_{4}{ }^{+}+\mathrm{NO}_{2}{ }^{-}$, and denitrification rates, with $\mathrm{NH}_{4}{ }^{+}+{ }^{15} \mathrm{NO}_{2}{ }^{-}$. The mean values from duplicate samples are shown, and the differences were less than $25 \%$ of the lower values.

nd: Not detected. The linear regression analysis of the ${ }^{29} \mathrm{~N}_{2}$ gas accumulated did not show a significant slope $(P<0.05)$.

—: Not determined.

Table 2. Concentrations of $\mathrm{NH}_{4}^{+}(\mu \mathrm{M})$ in bottom water, and pore water of the fs-layer $(0-2 \mathrm{~cm})$ and ss-layer $(10-12 \mathrm{~cm})$ of sediment collected at five stations (KUT-KU5) in Lake Kitaura

\begin{tabular}{lrrrrr}
\hline \multicolumn{1}{c}{ Samples } & KUT & KU3 & KUD & KU4 & KU5 \\
\hline August 1, 2005 & & & & & \\
$\quad$ bottom water & - & 12.1 & - & 21.5 & - \\
pore water $(0-2 \mathrm{~cm})$ & - & 115.9 & - & 149.4 & - \\
$\quad$ pore water $(10-12 \mathrm{~cm})$ & - & 116.5 & - & 211.5 & - \\
October 17, 2005 & & & & & \\
$\quad$ bottom water & 43.9 & 13.8 & - & 8.26 & - \\
pore water $(0-2 \mathrm{~cm})$ & 369.2 & 53.7 & - & 118.9 & - \\
$\quad$ pore water $(10-12 \mathrm{~cm})$ & 2549.0 & 191.9 & - & 470.4 & - \\
April 17, 2006 & & & & & \\
$\quad$ bottom water & - & 0.97 & 3.05 & 2.18 & - \\
$\quad$ pore water $(0-2 \mathrm{~cm})$ & - & 5.89 & 31.6 & 70.2 & - \\
$\quad$ pore water $(10-12 \mathrm{~cm})$ & - & 40.8 & 82.8 & 165.0 & - \\
June 7, 2006 & - & 0.0 & - & 20.0 & 30.7 \\
$\quad$ bottom water & - & 45.7 & - & 40.0 & 76.7 \\
pore water $(0-2 \mathrm{~cm})$ & - & 98.0 & - & 47.7 & 71.9 \\
$\quad$ pore water $(10-12 \mathrm{~cm})$ & - & & & & \\
\hline
\end{tabular}

—: Not determined.

of the dynamics of anammox bacteria in Lake Kitaura. On the other hand, the artificial medium may yield higher anammox rates than those in situ. It should be noted that the potential anammox activity in this study demonstrates the existence of an anammox bacterial population (probably its size also) and dose not necessarily reflect in situ activity. Therefore the anammox rates determined in this study, which 
Table 3. Concentrations of $\mathrm{NO}_{3}^{-}(\mu \mathrm{M})$ in bottom water, and pore water of the fs-layer $(0-2 \mathrm{~cm})$ and ss-layer $(10-12 \mathrm{~cm})$ of sediment collected at five stations (KUT-KU5) in Lake Kitaura.

\begin{tabular}{lrrrrr}
\hline \multicolumn{1}{c}{ Samples } & KUT & KU3 & KUD & KU4 & KU5 \\
\hline August 1, 2005 & & & & & \\
$\quad$ bottom water & - & 158.8 & - & 46.0 & - \\
pore water $(0-2 \mathrm{~cm})$ & - & 46.7 & - & 32.3 & - \\
pore water $(10-12 \mathrm{~cm})$ & - & 86.3 & - & 45.9 & - \\
October 17, 2005 & & & & & \\
bottom water & 337.1 & 272.2 & - & 157.9 & - \\
pore water $(0-2 \mathrm{~cm})$ & 33.0 & 31.9 & - & 3.26 & - \\
pore water $(10-12 \mathrm{~cm})$ & 28.7 & 31.7 & - & 32.9 & - \\
April 17, 2006 & & & & & \\
bottom water & - & 276.5 & 240.0 & 185.2 & - \\
pore water $(0-2 \mathrm{~cm})$ & - & 42.6 & 6.30 & 2.38 & - \\
pore water $(10-12 \mathrm{~cm})$ & - & 1.51 & 2.06 & 1.33 & - \\
June 7, 2006 & & & & & \\
bottom water & - & 25.4 & - & 12.3 & 6.33 \\
pore water $(0-2 \mathrm{~cm})$ & - & 0.77 & - & 0.84 & 1.52 \\
pore water $(10-12 \mathrm{~cm})$ & - & 0.74 & - & 0.46 & 0.38 \\
\hline
\end{tabular}

- : Not determined.

are potential rates, could not be compared with the in situ rates determined in most other reports.

$\mathrm{NH}_{4}{ }^{+}$and $\mathrm{NO}_{2}{ }^{-}$function as the electron donor and acceptor for anammox, respectively, and are important in the ecology and physiology of anammox bacteria (14). Generally in sediment of a freshwater lake, $\mathrm{NH}_{4}{ }^{+}$is adsorbed to negatively charged clay minerals and continuously supplied via equilibrium into the ambient pore water. In fact, appreciable concentrations $(>5 \mu \mathrm{M})$ of $\mathrm{NH}_{4}{ }^{+}$were in pore water of the fs- and ss-layers at every station (Table 3 ). Therefore, $\mathrm{NH}_{4}{ }^{+}$ may not be a limiting factor for anammox metabolism in these layers. Trimmer and colleagues suggested that the penetration of a high concentration of $\mathrm{NO}_{3}{ }^{-}$from overlying water into the sediment and the subsequent reduction of $\mathrm{NO}_{3}{ }^{-}$ to $\mathrm{NO}_{2}{ }^{-}$promote anammox activity in sediment of the Thames River estuary (31). Several other reports also proposed that a consistent and available supply of $\mathrm{NO}_{3}{ }^{-}$is a prerequisite for maintaining an anammox population in estuarine and marine sediments $(16,19,20,31,32)$. In this study, bottom water retained $\mathrm{NO}_{3}{ }^{-}$at relatively high concentrations at all stations on every sampling occasion (Table 2). Pore water of the fs- and ss-layers also retained $\mathrm{NO}_{3}^{-}$; at station $\mathrm{KU} 3,0.8-$ $46.7 \mu \mathrm{M}$ of $\mathrm{NO}_{3}^{-}$was observed in the fs-layer, and up to $86.3 \mu \mathrm{M}$ of $\mathrm{NO}_{3}{ }^{-}$was retained in the ss-layer. This suggests that $\mathrm{NO}_{2}^{-}$, the electron acceptor in anammox, could be continuously supplied via reduction of $\mathrm{NO}_{3}{ }^{-}$in the fs- and ss-layers at stations KUT-KU5.

\section{Horizontal distribution of anammox and denitrification activities (potential) in Lake Kitaura}

To survey the horizontal distribution of anammox bacteria in Lake Kitaura, the potential anammox activity in sediment was measured throughout the lake on November 8, 2005. We preferred to use sediment from the ss-layer instead of the fslayer because of its texture and more stable and reproducible anammox activity (Table 1 ). As a result, potential anammox activity at rates greater than $1.0 \mathrm{nmol}-\mathrm{N}_{2} \mathrm{~cm}^{-3} \mathrm{~h}^{-1}$ was detected at the northern stations KU1, KU2, KU3, KU4, and KU5

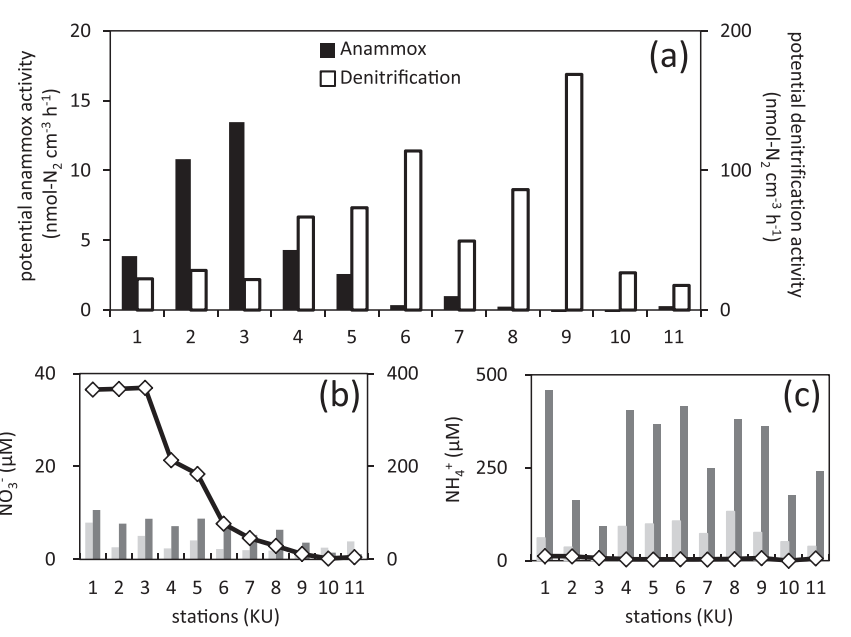

Fig. 3. (a) Potential anammox (black bars, left y-axis) and denitrification (white bars, right $\mathrm{y}$-axis) activities in the ss-layer $(10-12 \mathrm{~cm})$ of sediment at 11 stations (KU1-KU11) of Lake Kitaura on November 8,2005 . The anammox rates were estimated from the incubation with ${ }^{15} \mathrm{NH}_{4}^{+}+\mathrm{NO}_{2}^{-}$, and the denitrification rates, with $\mathrm{NH}_{4}{ }^{+}+{ }^{15} \mathrm{NO}_{2}^{-}$. Incubations were performed in duplicate and the mean values are shown. Concentrations of (b) $\mathrm{NO}_{3}{ }^{-}$and (c) $\mathrm{NH}_{4}{ }^{+}$in bottom water (diamonds) and pore water of the fs-layer $(0-2 \mathrm{~cm}$, light gray bar) and ss-layer (10-12 cm, gray bar) are also shown. Note that $\mathrm{NO}_{3}{ }^{-}$concentrations in bottom water are shown on the right axis.

(Fig. 3a), and the highest potential activity was observed at $\mathrm{KU} 3$ with a rate of $13.5 \mathrm{nmol}-\mathrm{N}_{2} \mathrm{~cm}^{-3} \mathrm{~h}^{-1}$. In contrast, evidential anammox activity was not detected at the remaining six stations in the southern region of the lake. Unlike the distribution of anammox, potential denitrification activities were detected throughout the stations in the lake, ranging from 11.7 to $168.7 \mathrm{nmol}-\mathrm{N}_{2} \mathrm{~cm}^{-3} \mathrm{~h}^{-1}$, and were higher than anammox activity at each station (Fig. 3a). Interestingly, the denitrification rate was relatively low at station $\mathrm{KU} 3$, where the highest potential anammox activity was detected. Consequently, the potential anammox activity at station KU3 corresponded to ca. $40 \%$ of total $\mathrm{N}_{2}$ production (anammox+denitrification), defined as an "anammox hot spot".

The $\mathrm{NO}_{3}{ }^{-}$concentrations in the bottom water decreased drastically along the water stream from north $(\mathrm{KU} 1,370 \mu \mathrm{M})$ to south (KU11, $1.7 \mu \mathrm{M} \mathrm{NO}_{3}{ }^{-}$), and up to $10.6 \mu \mathrm{M}$ of $\mathrm{NO}_{3}{ }^{-}$ was detected in pore water even in the ss-layer at stations except the two southernmost stations (Fig. 3b), suggesting that $\mathrm{NO}_{2}^{-}$could be supplied to the anammox bacteria through reduction of $\mathrm{NO}_{3}{ }^{-}$. The other anammox substrate $\mathrm{NH}_{4}{ }^{+}$was abundantly present in pore water at all stations (Fig. 3c). Notably, $200 \mu \mathrm{M}$ of $\mathrm{NO}_{3}{ }^{-}$was present in the bottom water at stations KU1-KU5, located in the northern and upstream region of the lake, where potential anammox activities were detected in the ss-layers. These results suggest the $\mathrm{NO}_{3}{ }^{-}$pool in the bottom water to be a limiting factor for the development of anammox bacterial population in the sediment, as suggested in estuarine and marine sediments $(7,19)$.

Beside nitrate and ammonium ion profiles, sulfate, sodium and chloride ions and total organic carbon content (TOC) were measured (Fig. S1). The concentrations of sulfate, sodium and chloride did not change considerably from north to south, except that a higher sulfate concentration was observed in the ss-layer at station KU3, the "anammox hot spot". It is unclear why the high concentration of sulfate 
was accumulated specifically at KU3 and how the sulfate and associated bacteria influenced the anammox bacterial population. Furthermore, the gradual increase of TOC in bottom water from north to south seemed to stimulate the heterotrophic denitrifying bacteria shown in Fig. 3a. The denitrifiers in the sediment could have possibly outcompeted anammox bacteria for $\mathrm{NO}_{2}^{-}$acquisition in the southern region of the lake because potential denitrification activity increased gradually from station KU3 to station KU6 while potential anammox activity decreased (Fig. 3a).

\section{Population structure analysis of anammox bacteria in Lake Kitaura}

The PCR-clone library analysis targeting 16S rRNA genes of anammox bacteria was performed with environmental DNA extracted from sediment sampled on November 8, 2005 to analyze the population structure of anammox bacteria in Lake Kitaura. PCR amplicons with the expected length (ca. $450 \mathrm{bp}$ ) were successfully obtained from the sediment samples of stations KU1 to KU5 in which anammox activity was detected, whereas no amplicon was obtained from stations KU7 to KU11 with both AMX368F-AMX820R and AMX368F-BS820R in 30 PCR cycles. Interestingly, amplicons were obtained from the sample at KU6, even though significant $\mathrm{N}_{2}$ production via anammox was not detected. It is likely that anammox bacteria were present at KU6 but their population size was too small to detect the anammox activity or they were metabolically inactive. Six clone libraries were constructed from PCR products amplified from samples of stations KU1 to KU6, and more than 40 clones of each library were sequenced. In agreement with our previous study (2), no differences were observed in the sequence compositions of the clone libraries amplified with primer AMX820R for "Brocadia/Kuenenia"-lineages or primer BS820R for "Scalindua"-lineages from the same sediment samples in Lake Kitaura (data not shown). Furthermore, neither the primer set with AMX820R nor BS820R detected "Scalindua"-lineages. Therefore, clone libraries constructed from PCR products using AMX368F-AMX820R were analyzed.

A total of 275 clones were sequenced, and clones with greater than $83 \%$ sequence similarity to any known anammox bacteria were tentatively defined as anammox bacteriarelated 16S rRNA gene clones, AMX-clones, in accordance with a previous study (2). The recovery frequency (the number of AMX-clones as a percentage of the total number of clones sequenced) of our selective PCR at stations KU1, KU2, KU3, KU4, KU5 and KU6 was 95, 98, 100, 100, 100 and $90 \%$, respectively. Finally, we identified 268 AMXclones that were in a monophyletic branch with members of Brocadiales on a phylogenetic tree including non-anammox Planctomycetes. The 268 AMX-clones were divided into 32 OTUs using a cutoff value of $99 \%$ sequence similarity with the furthest neighbor algorithm in the DOTUR 1.53 program (Fig. 4). When we set the cut-off value to $1 \%$ sequence variation, the predicted number of OTUs by Chaol estimator was 47.2 , suggesting that the anammox bacterial population in the sediment is composed of diverse Brocadiales species (Table S1). The numbers of OTU in each site predicted by Chao 1 estimator ranged from 9.3 to 23.0 , but there was no definite correlation between them and the location or the strength of anammox activities. The Shannon Index and Simpson Index did not have a noticeable correlation with the location and/or the distribution of anammox activity (Table S1).

The lineage related to the genus "Brocadia" comprised 17 OTUs (OTU-5 to OTU-21) and constituted 76.4\% (204/ 268) of all the AMX-clones sequenced in this study. Most of these clones were classified as either OTU-11 (86 clones) or OTU-16 (62 clones). The pair-wise sequence similarity values between the OTU-11 and OTU-16 members were at most $96.8 \%$, and the value with $\mathrm{Ca}$. "Brocadia fulgida", the closest anammox bacterial species, were less than $95.2 \%$ (OTU-11) and 96.6\% (OTU-16). Members of OTU-16 and OTU-17 were closely related to AMX-clones previously obtained from estuarine sediments of the Yodo River (AB300480 and AB300485) (2) with an average sequence similarity of $99.4 \%$. Recently, $16 \mathrm{~S}$ rRNA genes of the "Brocadia"-lineage have been recovered from various environments. Clones amplified by selective PCR from terrestrial soils and ground water tables (terrestrial clones: FM174253, FM174254 and FM174262) (12) belonged to the same lineage as OTU-16. 16S rRNA gene clones related to OTU-16 were also retrieved from the water column of a stratified lake (FJ830384 and FJ830386), Osaka Bay sediment (AB303294) and the Cape Fear River estuary $(2,6,9)$. The branch including OTU-16 and OTU-17 and the other three OTUs (OTU-15, -18 and -19) were tentatively defined as phylotype B2. However, OTU-11 and its relatives (OTU-10, -12, -13 and -14), the other predominant AMX-clones recovered from the Lake Kitaura sediment, are distantly related to the "Brocadia"-lineage sequences in the database. Several OTUs formed a single branch (Fig. 4) with $\mathrm{Ca}$. "B. anammoxidans", the other species of the genus "Brocadia", but had low sequence similarity values. These results suggest that the anammox bacterial population in the sediment of Lake Kitaura was predominantly composed of a variety of "Brocadia"-like species, most of which are currently unidentified.

A cluster composed of 38 AMX-clones that were classified as 8 OTUs (OTU-24 to OTU-32) was relatively close to $C a$. "J. asiatica", and $C a$. "A. propionicus". However, the sequence similarity between the type strains was $<93.5 \%$. Some anammox bacterial clones of the "Jettenia/Anammoxoglobus"-lineage have been reported in terrestrial ecosystems and the coastal seabed of Osaka Bay (AB303295). In Lake Kitaura, novel 16S rRNA gene clones related to the "Jettenia/Anammoxoglobus"-lineage but phylogenetically different from the anammox bacteria in other locations were observed in the sediment with potential anammox activity. We recovered 25 clones of 6 OTUs (OTU-1 to OTU-6) relatively close to $C a$. "K. stuttgartiensis" although their sequence similarity values were low (94.8\% at most). However several AMX-clones in the database recently isolated from lakeshore soil (FM174261) and groundwater (AJ871743) were phylogenetically related to members of OTU-1 and OTU-2, with similarity values of $>98 \%$. The AMX-clones related to $\mathrm{Ca}$. "K. stuttgartiensis" have been discovered by PCR from hydrothermal vents (4), the Cape Fear River estuary (6) and various terrestrial environments 


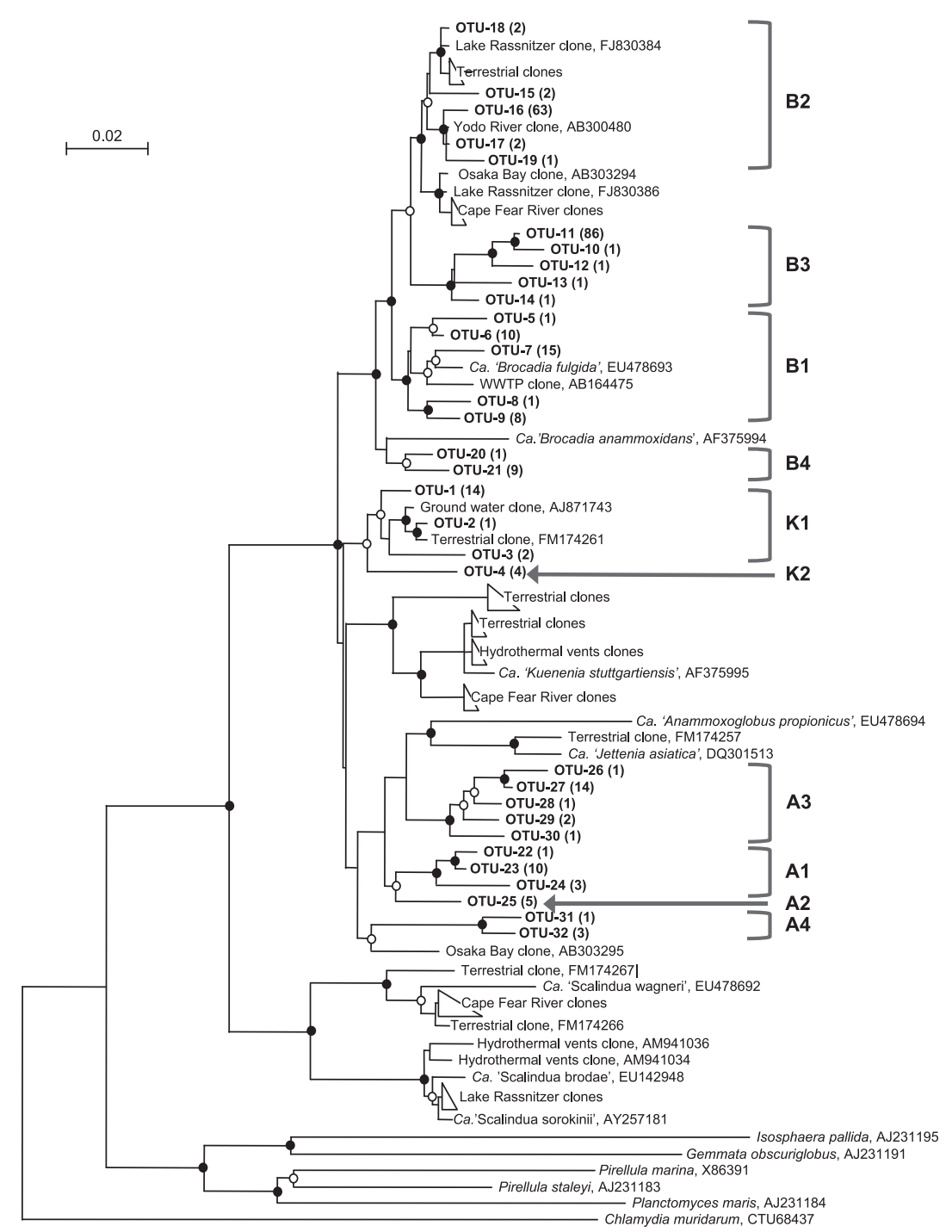

Fig. 4. A phylogenetic relationship showing anammox-related 16S rRNA gene clones (AMX-clones, partial) derived from the ss-layer (10-12 $\mathrm{cm}$ ) of sediment samples in Lake Kitaura on November 8, 2005. Sequences from several anammox bacterial species, Candidatus "Brocadia anammoxidans", $\mathrm{Ca}$. "B. brodae", $\mathrm{Ca}$. "Kuenenia stuttgartiensis", $\mathrm{Ca}$. "Anammoxoglobus propionicus", $\mathrm{Ca}$. "Jettenia asiatica" and $\mathrm{Ca}$. "Scalindua sorokinii", and environmental clones were obtained. The triangles at the end of branches include several environmental clones. Operational taxonomic units (OTUs) from Lake Kitaura are shown in bold and the number of clones belonging to each OTU is shown in parentheses. Solid and open circles on the nodes indicate bootstrap values higher than $70 \%$ and $50 \%$, respectively. The bar represents $2 \%$ substitution per nucleotide. Ten phylotypes (B1-B4, K1, K2, A1-A4) of 16S rRNA gene clones (OTUs) from Lake Kitaura are also shown.

(12), but the sequence similarity between them and our AMX-clones from Lake Kitaura was not significantly high.

In our investigation, a $16 \mathrm{~S}$ rRNA gene fragment phylogenetically close to the "Scalindua"-lineages in databases was not amplified from sediment samples in which the anammox activity was observed, even using the primer for this group, BS820. This indicates that $\mathrm{Ca}$. "Scalindua"-like organisms are likely not to contribute to the anammox activity in the sediment of Lake Kitaura, although Schmid and colleagues reported that $\mathrm{Ca}$. "S. sorokinii"-like organisms are commonly observed in marine environments (24). Ca. "S. sorokinii"-lineages have also been reported in the water column of freshwater lakes (Lake Tanganyika and Lake Rassnitzer) $(9,25)$ and in freshwater sediments of a Chinese river (35). Dale and colleagues recently reported that an anammox bacterial population dominated by "Brocadia"-like species in a river system shifted to a population including more "Scalindua"-like species as the salinity increased at the estuary (6), suggesting salinity to be a crucial environmental factor for "Scalindua"-lineages. The salinity of the sampling sites in Lake Kitaura is generally low, and the water is separated from a marine environment by estuary barrages. Thus, it is likely that the anammox bacterial population in Lake Kitaura is predominantly composed of "Brocadia"- and "Kuenenia"-like organisms.

Thirty-two OTUs of AMX-clones were tentatively categorized into 10 phylotypes as shown in Fig. 4, and the phylotype composition was compared between the sampling sites (Fig. 5). Each phylotype consists of the OTUs related to each other with $97 \%$ sequence similarity, suggesting the same species at the phylogenetical level. Phylotype B3 was composed of 90 AMX-clones including OTU-11 and was ubiquitously distributed from stations KU1 to KU6, while the second dominant phylotype B2 which included OTU-16 


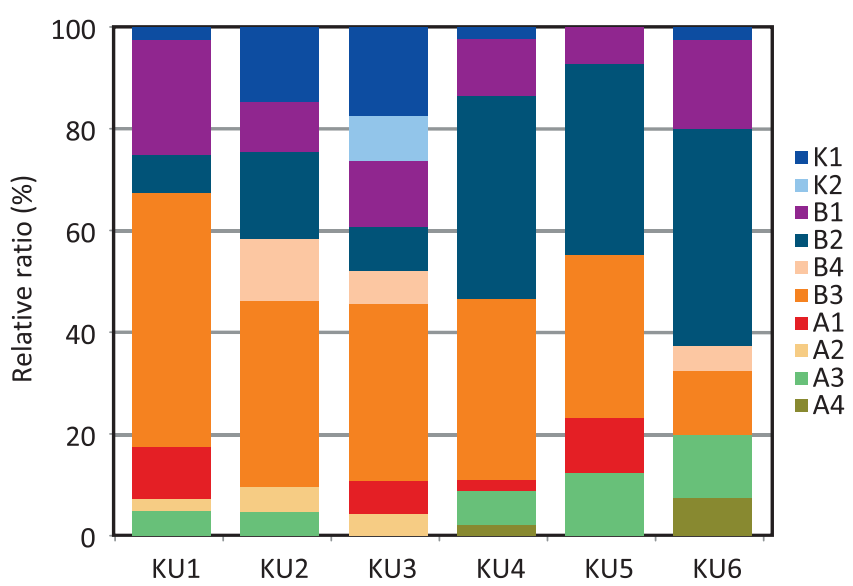

Fig. 5. Phylotype composition of anammox-related $16 \mathrm{~S}$ rRNA gene clones (AMX-clones) in the ss-layer of sediment samples at stations KU1-KU6. The phylotypes are shown in Fig. 4.

was relatively abundant at stations KU4, KU5 and KU6. Phylotypes $\mathrm{K} 1$ and $\mathrm{K} 2$, the phylotypes close to $\mathrm{Ca}$. "K. stuttgartiensis", were relatively abundant at stations KU2 and KU3 compared with the other stations, indicating that they might be more adapted at these stations. Environmental clones AJ871743 and FM174261 that were phylogenetically close to the phylotypes $\mathrm{K} 1$ and K2 (Fig. 4) were recently detected from groundwater and the rhizosphere of lakeshore plants in Switzerland. While no information regarding the groundwater and aquifer microorganisms of Lake Kitaura is available, the impact of groundwater penetration on the anammox bacterial population must be considered, because groundwater with a high nitrate concentration could provide necessary resources for anammox bacteria. Fig. 5 also revealed that a wide variety of Brocadiales species co-exist in the sediment of Lake Kitaura where potential anammox activity was detected.

To analyze the difference and relatedness among the anammox bacterial population at sampling sites, the UniFrac web interface (15) was used based on the phylotypes (>97\% sequence similarity) in Fig. 4, as well as the DOTUR software (Table S2). Both the p-test significance and the UNIFRAC significance indicated no apparent pair-wise difference $(P>0.1)$ in the population structures of anammox bacteria between sampling sites. However, a principal coordinate analysis (PCA) by the weighted distance matrix of six sampling sites showed that the population structures of anammox bacteria in the northern and upper area of the lake (stations KU1, KU2 and KU3) were different from those in the lower area (KU4, KU5 and KU6) with 53.25\% variation (PC1 on Fig. 6). The indices of diversity, the Shannon Index and Simpson's Index, determined by DOTUR with a cut-off value of 0.03 also indicate that more diverse species composed of the anammox bacterial population at KU2 and KU3, where high anammox activity (potential) was detected (Fig. 5, Table S2).

The metabolic versatility of anammox bacteria has recently been studied, and genomic information predicts that electron acceptors other than nitrite, such as Fe (III) and Mn (IV), might be utilized by anammox bacteria (28). Ca. "Anammoxoglobus propionicus" could utilize low molecular weight organic acids for energy acquisition pathways other than

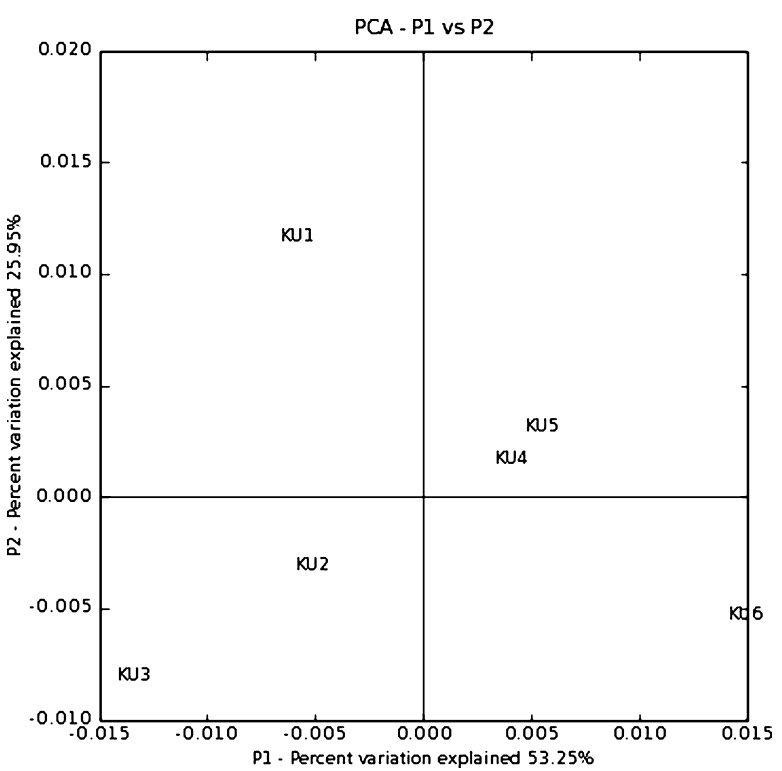

Fig. 6. Principal coordinates analysis generated using UNIFRAC with OTUs of 16SrRNA gene (Fig. 4) recovered from stations KU1KU6. The first and second principal coordinate (P1 and P2) are shown.

anammox (8). Such metabolic versatility of anammox bacteria may allow the coexistence of several anammox bacterial species in Lake Kitaura. However, it is difficult to isolate and investigate physiological characteristics of anammox bacteria that predominantly occur in limnetic ecosystems. More information on the horizontal and vertical distribution, especially in micro-scale environments, and seasonal fluctuation of each phylotype (species) of anammox bacteria should help to characterize their ecological niche and estimate their contribution to the nitrogen cycle. An improved fluorescent in situ hybridization (FISH) protocol and quantitative PCR targeting the AMX-clones described in this study may be useful in future studies.

The present survey revealed that anammox bacteria inhabit the sediment of a eutrophic freshwater lake in Japan, Lake Kitaura, which receives high $\mathrm{N}$ loads from nearby human activities. The rates of potential anammox activities in the sediment were similar to or even higher than those previously reported (36), and were present down to a depth of $10 \mathrm{~cm}$ beneath the water-surface boundary. Although the anammox activity measured by our protocol is "potential" activity and might be overestimated compared to that determined as in situ activity, the anammox bacterial population was stably established in this eutrophic lake, and their contribution to total $\mathrm{N}_{2}$ emission would not be negligible. A stable supply of $\mathrm{NO}_{3}{ }^{-}$, the nitrogenous compound convertible to $\mathrm{NO}_{2}{ }^{-}$that is an electron acceptor for anammox metabolism, from overlaying lake water seems to be crucial to the formation of an anammox bacterial population in sediment. A detailed study on the vertical profile of anammox bacteria and other bacterial populations as well as on the chemical and physiological profiles and dynamics in the sediment in the northern area of Lake Kitaura should help unveil the nature of the ecological niche of anammox bacteria. 


\section{Acknowledgements}

We express our gratitude to the late Saburo Taguchi and to Goro Koshikawa for their generous support as fishermen during the sampling on Lake Kitaura and to Yoshinao Ohtake and Masami Negishi for providing scientific information regarding the lake. This study was supported by the Experimental Research Budget for Pollution Prevention and Natural Environmental Conservation from the Japanese Ministry of the Environment.

\section{References}

1. Altschul, S.F., T.L. Madden, A.A. Schäffer, J. Zhang, Z. Zhang, W. Miller, and D.J. Lipman. 1997. Gapped BLAST and PSI-BLAST: A new generation of protein database search programs. Nucleic Acids Res. 25:3389-3402.

2. Amano, T., I. Yoshinaga, K. Okada, T. Yamagishi, S. Ueda, A Obuchi, Y. Sako, and Y. Suwa. 2007. Detection of anammox activity and diversity of anammox bacteria-related $16 \mathrm{~S}$ rRNA genes in coastal marine sediment in Japan. Microbes Environ. 22:232-242.

3. Amano, T., I. Yoshinaga, T. Yamagishi, C.V. Thuoc, P.T. Thu, S. Ueda, K. Kato, Y. Sako, and Y. Suwa. 2011. Contribution of anammox bacteria to benthic nitrogen cycling in a mangrove forest and shrimp ponds, Haiphong, Vietnam. Microbes Environ. 26:1-6.

4. Byrne, N., M. Strous, V. Crepeau, et al. 2009. Presence and activity of anaerobic ammonium-oxidizing bacteria at deep-sea hydrothermal vents. ISME J. 3:117-123.

5. Chenna, R., H. Sugawara, T. Koike, R. Lopez, T.J. Gibson, D.G. Higgins, and J.D. Thompson. 2003. Multiple sequence alignment with the Clustal series of programs. Nucleic Acids Res. 31:34973500 .

6. Dale, O., C. Tobias, and B. Song. 2009. Biogeographical distribution of diverse anaerobic ammonium oxidizing (anammox) bacteria in Cape Fear River Estuary. Environ. Microbiol. 11:1194-1207.

7. Dalsgaard, T., B. Thamdrup, and D.E. Canfield. 2005. Anaerobic ammonium oxidation (anammox) in the marine environment. Res. Microbiol. 156:457-464.

8. Güven, D., A. Dapena, B. Kartal, et al. 2005. Propionate oxidation by and methanol inhibition of anaerobic ammonium-oxidizing bacteria. Appl. Environ. Microbiol. 71:1066-1071.

9. Hamersley, M.R., D. Woebken, B. Boehrer, M. Schultze, G. Lavik, and M. Kuypers. 2009. Water column anammox and denitrification in a temperate permanently stratified lake (Lake Rassnitzer, Germany). Syst. Appl. Microbiol. 32:571-582.

10. Homma, T., N. Komatsu, M. Negishi, Y. Katagami, K. Nakamura, and H. Park. 2008. Influence of dissolved inorganic nitrogen and phosphorus concentrations on the horizontal and temporal changes of microcystis population in Lake Kitaura, p. 1423-1429. In M Sengupta, and R. Dalwani (ed.), Proceedings of Taal2007: The 12 World Lake Conference.

11. Huber, T., G. Faulkner, and P. Hugenholtz. 2004. Bellerophon: A program to detect chimeric sequences in multiple sequence alignments. Bioinformatics 20:2317-2319.

12. Humbert, S., S. Tarnawski, N. Fromin, M.P. Mallet, M. Aragno, and J. Zopfi. 2010. Molecular detection of anammox bacteria in terrestrial ecosystems: Distribution and diversity. ISME J. 4:450-454.

13. Jaeschke, A., H.J. Op den Camp, H. Harhangi, A. Klimiuk, E.C. Hopmans, M.S.M. Jetten, S. Schouten, and J.S. Sinninghe Damsté 2009. 16S rRNA gene and lipid biomarker evidence for anaerobic ammonium-oxidizing bacteria (anammox) in California and Nevada hot springs. FEMS Microbiol. Ecol. 67:343-350.

14. Jetten, M.S.M., L. van Niftrik, M. Strous, B. Kartal, J.T. Keltjens, and H.J.M. Op den Camp. 2009. Biochemistry and molecular biology of anammox bacteria. Crit. Rev. Biochem. Mol. Biol. 44:65-84.

15. Lozupone, C., and R. Knight. 2005. Unifrac: A new phylogenetic method for comparing microbial communities. Appl. Environ. Microbiol. 71:8228-8235

16. Meyer, R.L., N. Risgaard-Petersen, and D.E. Allen. 2005. Correlation between anammox activity and microscale distribution of nitrite in a subtropical mangrove sediment. Appl. Environ. Microbiol. 71:61426149.
17. Penton, C.R., A.H. Devol, and J.M. Tiedje. 2006. Molecular evidence for the broad distribution of anaerobic ammonium-oxidizing bacteria in freshwater and marine sediments. Appl. Environ. Microbiol. 72:6829-6832.

18. Rich, J.J., O.R. Dale, B. Song, and B.B. Ward. 2008. Anaerobic ammonium oxidation (Anammox) in Chesapeake Bay sediments. Microb. Ecol. 55:311-320.

19. Risgaard-Petersen, N., R.L. Meyer, and N.P. Revsbech. 2005 Denitrification and anaerobic ammonium oxidation in sediments: Effects of microphytobenthos and $\mathrm{NO}_{3}{ }^{-}$. Aquat. Microb. Ecol. 40:6776.

20. Rysgaard, S., and R.N. Glud. 2004. Anaerobic $\mathrm{N}_{2}$ production in Arctic sea ice. Limnol. Oceanogr. 49:86-94.

21. Saitou, N., and M. Nei. 1987. The neighbor-joining method: A new method for reconstructing phylogenetic trees. Mol. Biol. Evol. 4:406425.

22. Schloss, P.D., and J. Handelsman. 2005. Introducing DOTUR, a computer program for defining operational taxonomic units and estimating species richness. Appl. Environ. Microbiol. 71:15011506.

23. Schmid, M.C., B. Maas, A. Dapena, et al. 2005. Biomarkers for in situ detection of anaerobic ammonium-oxidizing (anammox) bacteria. Appl. Environ. Microbiol. 71:1677-1684.

24. Schmid, M.C., N. Risgaard-Petersen, J. van de Vossenberg, et al. 2007. Anaerobic ammonium-oxidizing bacteria in marine environments: Widespread occurrence but low diversity. Environ. Microbiol. 9:1476-1484

25. Schubert, C.J., E. Durisch-Kaiser, B. Wehrli, B. Thamdrup, P. Lam, and M.M.M. Kuypers. 2006. Anaerobic ammonium oxidation in a tropical freshwater system (Lake Tanganyika). Environ. Microbiol. $8: 1857-1863$

26. Smith, V.H., and D.W. Schindler. 2009. Eutrophication science: Where do we go from here? Trends Ecol. Evol. 24:201-207.

27. Spott, O., and C.F. Stange. 2007. A new mathematical approach for calculating the contribution of anammox, denitrification and atmosphere to an $\mathrm{N}_{2}$ mixture based on a ${ }^{15} \mathrm{~N}$ tracer technique. Rapid Commun. Mass Spectr. 21:2398-2406.

28. Strous, M., E. Pelletier, S. Mangenot, et al. 2006. Deciphering the evolution and metabolism of an anammox bacterium from a community genome. Nature 440:790-794.

29. Thamdrup, B., and T. Dalsgaard. 2002. Production of $\mathrm{N}_{2}$ through anaerobic ammonium oxidation coupled to nitrate reduction in marine sediments. Appl. Environ. Microbiol. 68:1312-1318.

30. Trimmer, M., J.C. Nicholls, and B. Deflandre. 2003. Anaerobic ammonium oxidation measured in sediments along the Thames estuary, United Kingdom. Appl. Environ. Microbiol. 69:6447-6454.

31. Trimmer, M., J.C. Nicholls, N. Morley, C.A. Davies, and J. Aldridge. 2005. Biphasic behavior of anammox regulated by nitrite and nitrate in an estuarine sediment. Appl. Environ. Microbiol. 71:1923-1930.

32. Trimmer, M., and J.C. Nicholls. 2009. Production of nitrogen gas via anammox and denitrification in intact sediment cores along a continental shelf to slope transect in the North Atlantic. Limnol. Oceanogr. 54:577-589.

33. van de Graaf, A.A., A. Mulder, P. de Bruijn, M.S.M. Jetten, L.A. Robertson, and J.G. Kuenen. 1995. Anaerobic oxidation of ammonium is a biologically mediated process. Appl. Environ. Microbiol. 61:1246-1251.

34. van de Graaf, A.A., P. de Bruijn, L.A. Robertson, M.S.M. Jetten, and J.G. Kuenen. 1996. Autotrophic growth of anaerobic ammoniumoxidizing micro-organisms in a fluidized bed reactor. Microbiology 142:2187-2196.

35. Zhang, Y., X.H. Ruan, H. den Camp, T.J.M. Smits, M.S.M. Jetten, and M.C. Schmid. 2007. Diversity and abundance of aerobic and anaerobic ammonium-oxidizing bacteria in freshwater sediments of the Xinyi River (China). Environ. Microbiol. 9:2375-2382.

36. Zhu, G., M.S.M. Jetten, P. Kuschk, K.F. Ettwig, and C. Yin. 2010. Potential roles of anaerobic ammonium and methane oxidation in the nitrogen cycle of wetland ecosystems. Appl. Microbiol. Biotechnol. $86: 1043-1055$. 